\title{
Tolerancja wodna etanolowych benzyn silnikowych
}

\begin{abstract}
Rosnące zainteresowanie wprowadzaniem odnawialnych komponentów paliw, w tym bioetanolu w przypadku benzyn silnikowych, spowodowało potrzebę zbadania możliwości wykorzystania tego składnika w ilościach większych niż obecnie dopuszczalne na rynku europejskim. Przedstawiana praca omawia aspekt odporności na wodę (tolerancji wodnej) tego rodzaju paliw - zawierających do $25 \%$ etanolu. Dodatkową motywacją podjęcia tego rodzaju badań była ocena możliwości zastosowania do komponowania paliw destylowanego etanolu, bez jego odwadniania. W pracy omówiono badania tolerancji wodnej benzyn zawierających $15 \%, 20 \%$ i $25 \%(V / V)$ etanolu oraz kompozycji z dodatkową zawartością 1\% (V/V) współrozpuszczalnika (izopropanol i/lub izobutanol). Stwierdzono, że tolerancja wodna kompozycji istotnie rośnie wraz ze wzrostem w niej ilości etanolu. Wpływ rodzaju współrozpuszczalnika jest mało efektywny i mieści się w granicach błędu pomiarowego, co wskazuje na brak potrzeby jego stosowania w przypadku kompozycji zawierających etanol w badanym zakresie stężeń. Jednocześnie zauważono zmniejszanie się różnic temperatur mętnienia i rozwarstwiania faz w miarę zwiększania udziału etanolu w kompozycji, co można wyjaśnić rosnącą zdolnością do koalescencji większej liczby powstających mikrokropli fazy wodno-etanolowej w jednostce objętości.
\end{abstract}

Słowa kluczowe: tolerancja wodna, bioetanol, benzyna silnikowa, temperatura mętnienia, rozwarstwienie faz.

\section{Water tolerance of motor gasoline-alcohol blends}

Due to the growing interest in using renewable fuel components, including ethanol in motor gasoline, it is necessary to investigate the possibility of using this component in quantities larger than those currently allowed on the European market. This paper discusses the aspect of water resistance (water tolerance) of fuel containing up to 25 vol. \% ethanol. Additional motivation to conduct this kind of research was to assess the possibility of using distilled ethanol in the formulation of fuels, without its additional dewatering. The paper discusses the test of water tolerance of gasoline containing 15, 20 and 25 vol. \% of bioethanol and compositions containing an additional 1 vol. \% of cosolvent (isopropanol and/or isobutanol). It has been found that the water tolerance of the bioethanol compositions significantly increases with the increase in the amount of ethanol. The influence of the co-solvent type is weak, and does not exceed measurement error; therefore it is not necessary to use co-solvent in compositions containing ethanol within the tested concentrations range. At the same time it was observed that the difference between cloud point and phase separation temperatures decreases with the increase in the amount of ethanol in the composition, which may be explained by the growing ability to coalesce a greater number of ethanol-water phase microdroplets forming per volume unit.

Key words: water tolerance, bioethanol, motor gasoline, cloud point, phase separation.

\section{Wstęp}

Malejące zasoby kopalnego surowca energetycznego ropy naftowej oraz zagrożenia związane $\mathrm{z}$ efektem cieplarnianym, powodowanym między innymi przez wprowadzanie do atmosfery ditlenku węgla powstającego podczas spalania paliw kopalnych, spowodowały zwiększenie zainteresowania surowcami roślinnymi, zapewniającymi akumulację węgla $\mathrm{z}$ atmosfery przez asymilację ditlenku węgla.
Wymaga to jednak przetworzenia materiału roślinnego do postaci płynnej, łatwej do wykorzystania w stosowanych silnikach spalinowych.

Etanol, alkohol etylowy, jest substancją ciekłą, produkowaną z popularnych surowców odnawialnych zawierających węglowodany, takich jak pszenica, jęczmień, kukurydza, ziemniaki (skrobia) czy trzcina cukrowa i buraki 
(sacharoza). Może być również wytwarzany z odpadów celulozowych, trocin, drewna, a także uzyskiwany przez syntezę z węglowodorów, etenu lub etanu.

Etanol może być stosowany bezpośrednio jako paliwo lub jako komponent podwyższający liczbę oktanową benzyny. Kompozycje zawierające do $10 \%(\mathrm{~V} / \mathrm{V})$ etanolu są obecnie powszechnie stosowane w USA i Kanadzie [19]. W Europie wykorzystuje się głównie benzyny z dodatkiem 5\% etano- lu $[1,15]$, niemniej ilość tego biokomponentu w paliwach systematycznie wzrasta, zgodnie z dyrektywą 2009/28/WE [28], przy czym już obecnie dopuszczono do powszechnego stosowania paliwa zawierające do $10 \%(\mathrm{~V} / \mathrm{V})$ etanolu. Rosnące zainteresowanie Komisji Europejskiej dalszym zwiększaniem udziału etanolu w paliwach, a także informacje o pracach prowadzonych w tym zakresie w UE wskazały, że istnieje potrzeba podjęcia analogicznych badań również w Polsce.

\section{Stan wiedzy}

Wykorzystanie etanolu jako nośnika energii spalanego w silnikach ma już ponad stuletnią historię. Już w 1896 r. Henry Ford zbudował swój pierwszy model pojazdu zasilanego czystym etanolem [9] (Ford Quadricycle), a w pięć lat po założeniu przez niego, w 1903 r., Ford Motor Company, w 1908 r., powstał samochód Ford T, zasilany etanolem produkowanym z kukurydzy, benzyną lub mieszaniną tych paliw. W latach dwudziestych XX wieku Standard Oil rozpoczęło stosowanie etanolu jako dodatku podwyższającego liczbę oktanową benzyn silnikowych. Można zauważyć, że możliwość wykorzystania etanolu jako paliwa w silnikach z zapłonem iskrowym, w których podstawowym komponentem jest benzyna, będąca złożoną mieszaniną węglowodorów, jest znana od dawna. Podstawową trudność stanowi tu ograniczona rozpuszczalność alkoholu w benzynie, zwłaszcza w przypadku obecności wody. Jedną z pierwszych prac poświęconych tej tematyce było opracowanie Bridgemana i Querfelda [3] z 1933 r., w którym przedstawiono wyniki badań krytycznych temperatur rozpuszczania (mieszalności) alkoholu i benzyny. Badaniami objęto osiem różnych amerykańskich benzyn silnikowych w mieszaninach zawierających od 10\% do 90\%
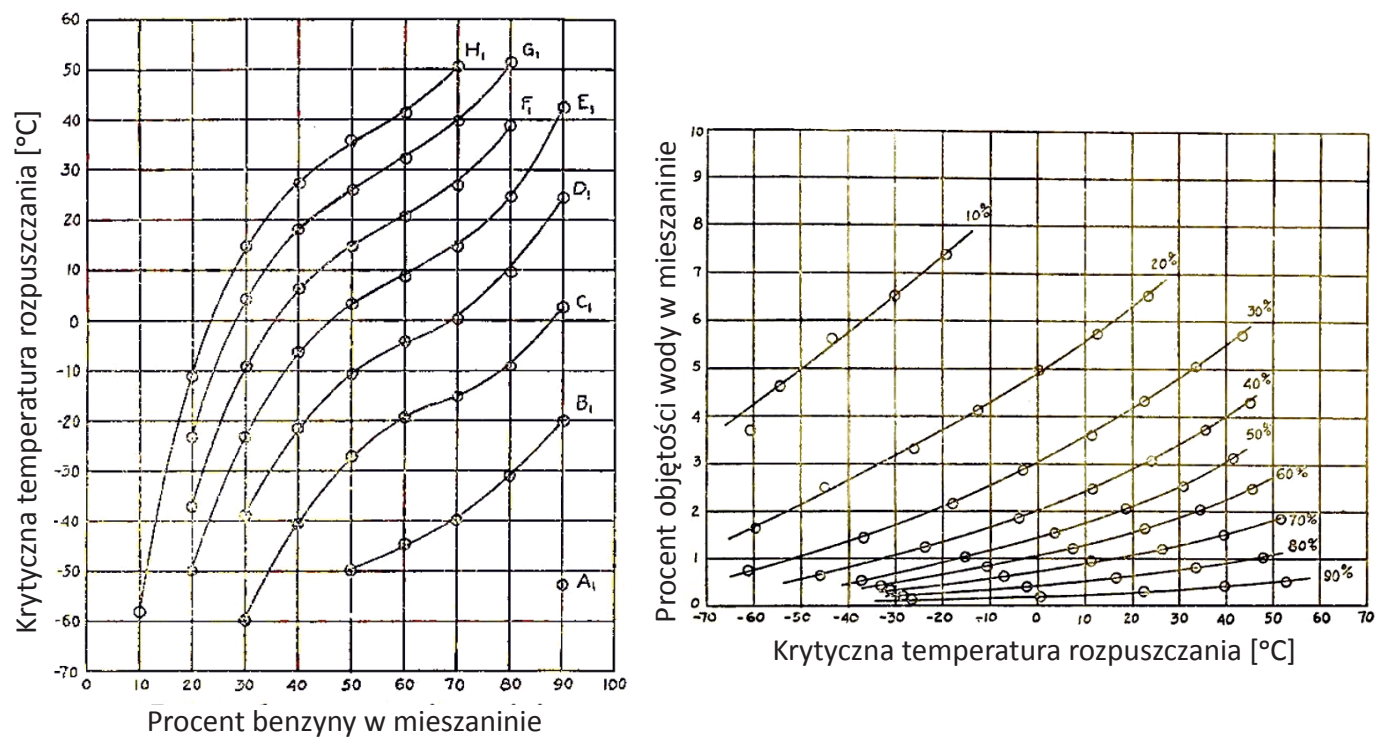

Rys. 1. Przykładowe wyniki badań krytycznych temperatur rozpuszczania wody w mieszaninach benzyny pochodzącej z Pensylwanii z etanolem (według [3]) badanej benzyny z ośmioma mieszankami wodno-alkoholowymi, zawierającymi od $1 \%$ do $8 \%(V / V)$ wody przy $15,6^{\circ} \mathrm{C}$. Stwierdzono, że temperatura krytyczna mieszania znacznie się obniża, gdy maleje stężenie wody w stosowanym etanolu, a przy tym w mieszaninie obniża się procentowy udział benzyny. Wywnioskowano również, że w przypadku obecności wody w alkoholu konieczne jest wykorzystanie innych substancji wspomagających rozpuszczalność, o ile nie używa się alkoholu niemal całkowicie bezwodnego. Wyniki badań wykazały, że mieszaniny badanych ośmiu benzyn z 95-procentowym alkoholem w równych proporcjach ulegają rozdziałowi na dwie fazy w przedziale temperatur od $14^{\circ} \mathrm{C}$ do $41^{\circ} \mathrm{C}$. Dodatkowo przy założeniu, że temperatura rozwarstwiania powinna być niższa niż $-20^{\circ} \mathrm{C}$, ilość stosowanego 95-procentowego etanolu nie może być niższa niż 90\%. Z drugiej strony przy wykorzystaniu 99-procentowego etanolu jego zawartość gwarantująca rozdział faz poniżej $-20^{\circ} \mathrm{C}$ może być niższa niż 10\%. Na rysunku 1 przedstawiono przykładowe wyniki badań jednej z benzyn.

Obecnie na świecie są stosowane różne paliwa silnikowe zawierające etanol. Jego zawartość w kompozycjach paliwowych waha się od 5\% do $25 \%$. Należy tu jednak zauważyć, że alkohol paliwowy (bioetanol), zawierający $80 \%$ do $95 \%$ etanolu, może być również wykorzystywany jako samodzielne paliwo, co jednak wymaga pewnych modyfikacji układu zasilania, gaźnika, elementów układu paliwowego, a często dostosowania współczynnika sprężania [2]. Zaletą takiego paliwa jest co prawda możliwość pominięcia operacji odwadniania alkoholu, jednak jego 
wadę stanowi brak odpowiedniej sieci dystrybucji. W sprawozdaniu EPA [24] opisano badania separacji faz w paliwach silnikowych E95 i E85 zawierających głównie etanol paliwowy (bioetanol). Stwierdzono, że pojawianie się fazy benzynowej w obu paliwach obserwuje się dopiero po dodaniu około 15\% wody. Obowiązujące w Polsce w 2009 r. specyfikacje jakościowe bioetanolu i biopaliw omówiły M. Pałuchowska i B. Danek [17].

Ogólnie można zauważyć, że obecnie jako paliwa do silników z zapłonem iskrowym wykorzystuje się powszechnie mieszaniny etanolowo-benzynowe zawierające do $25 \%$ bezwodnego etanolu albo paliwa zawierające nie mniej niż 15\% benzyny i nie więcej niż 85\% bezwodnego etanolu oraz etanol o średniej zawartości wody 5,3\% $(V / V)$, co pokazano na rysunku 2 [22].

\section{Powszechnie stosowane paliwa etanolowe do silników o zapłonie iskrowym}

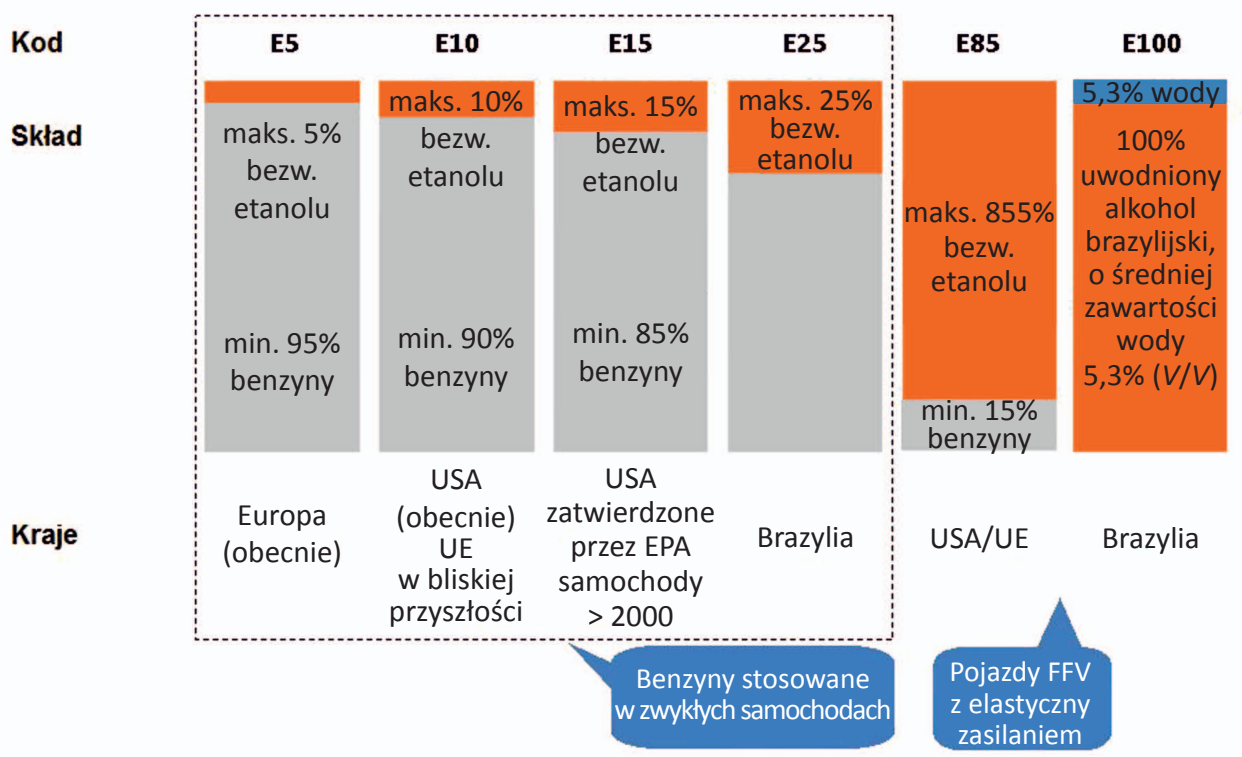

Rys. 2. Paliwa alkoholowe stosowane w silnikach samochodowych (na podstawie [22]) potraktowano tu jako mieszaniny trójskładnikowe węglowodorów parafinowo-naftenowych - aromatycznych i etanolu. Przedmiotem badań były: odaromatyzowana benzyna, wydzielone z niej frakcje benzenowa $(343 \div 368 \mathrm{~K})$, toluenowa $(368 \div 398 \mathrm{~K})$, ksylenowa $(398 \div 423 \mathrm{~K})$ i trimetylobenzenowa $(423 \div 453 \mathrm{~K})$ oraz indywidualne węglowodory (benzen, toluen, p-ksylen i pseudokumen). W pracy stwierdzono, że w etanolu rozpuszcza się nieznaczna ilość węglowodorów pochodzących z benzyny $(1 \div 3 \%$ objętościowych). Dlatego podczas mieszania benzyny i etanolu należy uznać, że benzyna rozpuszcza się w etanolu, ale nie odwrotnie. Mieszaninę frakcji benzynowej z etanolem można przedstawić jako układ trójskładnikowy - węglowodory aromatyczne, węglowodory parafinowo-naftenowe i etanol. Stwierdzono, że obszar tworzenia się mieszaniny heterogenicznej zmniejsza się wraz ze wzrostem temperatury i obniżaniem zawartości wody w etanolu, przy czym obszar dwufazowy rośnie przy obniżaniu się temperatury (wzrasta skłonność do rozwarstwiania się mieszaniny paliwowej).

$\mathrm{Z}$ tego względu kompozycje zawierające etanol w ilości do $10 \%(V / V)$ mają zwykle w swoim składzie substancje zapobiegające rozdziałowi faz - współrozpuszczalniki, z których często stosowane są alkohole takie jak izopropanol, a także izobutanol, będące przedmiotem wcześniejszych prac M. Pałuchowskiej [14, 16].

Wyniki badań benzyn silnikowych o wyższej zawartości etanolu w kompozycjach paliwowych opisano szczegółowo w opracowaniu AVL (Anstalt für Verbrennungskraftmaschinen List) [8].

Jak już wspomniano, benzyny zawierające jako komponent etanol mogą rozpuszczać znacznie więcej wody niż konwencjonalne benzyny węglowodorowe. W informacji Korotneya [13] kierowanej do normalizacyjnej grupy roboczej wskazano, że problem kontaktu $\mathrm{z}$ wodą tego rodzaju paliw należy traktować ze szczególną uwagą. Wodę, słabo rozpuszczalną w konwencjonalnej benzynie, która w niewielkiej ilości gromadziła się na dnie zbiornika, można było w prosty sposób usunąć mechanicznie. Woda w paliwach etanolowych po przekroczeniu stężenia krytycznego i rozdziale paliwa na dwie fazy usuwa w znacznym stopniu z paliwa komponent alkoholowy. Woda rozpuszczona w utworzonej fazie benzynowej może być traktowana jako składnik obojętny, niemający 
zasadniczego wpływu na procesy spalania w silniku, jednak usunięcie etanolu w istotny sposób zmienia ogólne właściwości paliwa, np. jego liczbę oktanową. Wpływ wody w fazie wodno-alkoholowej (praktycznie niepalnej) na pracę silnika jest różny w zależności od rodzaju silnika. W przypadku silnika czterosuwowego mogą wystąpić problemy z jego uruchamianiem i stabilnością działania. W pracy B. Danek [6] omówiono właściwości paliw etanolowych zawierających do 25\% ( $V / V)$ etanolu. Bardziej szczegółowe informacje na ten temat przedstawił w swojej pracy Z. Stępień [21], podkreślając jako efekt pozytywny stosowania etanolu wzrost liczby oktanowej paliw, a także możliwość podwyższenia stopnia sprężania, a co za tym idzie - uzyskania większego stopnia napełnienia cylindrów. Niemniej podkreślił on również konieczność rozwiązania problemów wynikających z porównania właściwości etanolu i konwencjonalnej benzyny, takich jak mniejsza wartość opałowa etanolu i jego wyższe ciepło parowania, co wiąże się z koniecznością zwiększenia zużycia paliwa z jednej strony, z drugiej zaś z podwyższeniem stopnia sprężania. Korzystne ze względów ekologicznych obniżenie emisji cząstek stałych przez wprowadzenie etanolu jako komponentu benzyny silnikowej jest związane z pogorszeniem jej właściwości smarnych i osiadaniem gniazd zaworowych. Zwiększenie zdolności rozpuszczających paliw zawierających etanol podobnie pogarsza warunki smarowania silnika, a dodatkowo może powodować dynamiczne przenoszenie osadów wymytych z elementów silnika i części układu paliwowego do filtrów i podzespołów układu wtrysku paliwa. Większa higroskopijność etanolu i jego powinowactwo do wody, a także skłonność paliw etanolowych do rozwarstwiania się po osiągnięciu określonego poziomu zawartości wody stwarzają zagrożenia związane z zaburzeniem procesów spalania, unieruchomieniem silnika oraz intensyfikacją procesów korozyjnych.

Waytulonis i wsp. [23] wskazali natomiast, że silniki dwusuwowe, których smarowanie zależne jest od oleju wprowadzanego z paliwem, moga po rozwarstwieniu benzyny etanolowej ulec nawet całkowitemu zniszczeniu.

W badaniach prowadzonych w Oak Ridge National Laboratory [18] wykazano, że zawartość wody w mieszankach etanolu $\mathrm{z}$ benzyną przed rozwarstwieniem w temp. $15,56^{\circ} \mathrm{C}$ $\left(60^{\circ} \mathrm{F}\right)$ wynosiły przy zawartościach etanolu 5,7\%, 7,7\% i $10 \%(V / V)$ odpowiednio $0,20 \%, 0,33 \%$ i $0,45 \%(V / V)$ wody. Na rysunku 3 pokazano zależność ilości wody rozpuszczalnej w badanej kompozycji benzyny z alkoholem od temperatury.

Wprowadzenie wody do paliw zawierających etanol powoduje utworzenie układu dwufazowego o drastycznie różnych właściwościach faz. W zależności od warunków od $40 \%$ do $80 \%$ etanolu jest usuwane $\mathrm{z}$ fazy benzynowej [5].
Tolerancja wody w mieszaninach benzyna/etanol

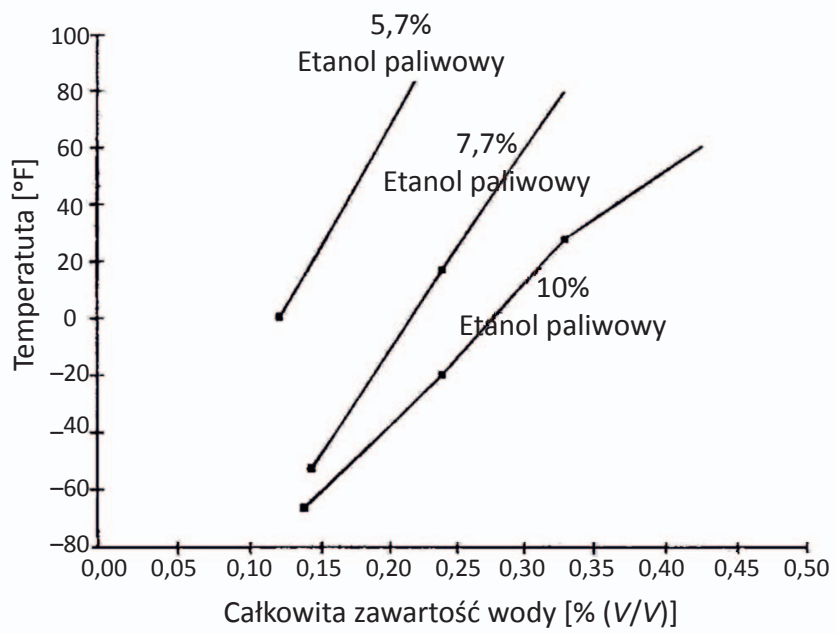

Rys. 3. Wpływ składu benzyny na tolerancję wody (według [18])

W interesującym opracowaniu S. Jaina dla firmy Veeder-Root [11], zajmującej się problemami magazynowania paliw, wskazano, że para wodna jest absorbowana w mieszaninach paliwo-etanol aż do osiągnięcia stanu nasycenia, co dla stosowanej w Stanach Zjednoczonych benzyny E10 wynosi $0,5 \%(V / V)$ wody przy $15^{\circ} \mathrm{C}$. Po wystąpieniu stanu nasycenia wydzielająca się woda gromadzi się na dnie zbiornika i zwykle zawiera mieszaninę trzech do czterech części alkoholu na każdą część wody. W przypadku zbiornika o średnicy około $3 \mathrm{~m}$ i wysokości około $5 \mathrm{~m}$ zawierającego $\sim 23 \mathrm{~m}^{3}$ benzyny E10 wystarczy około 1141 wody, aby spowodować całkowite oddzielenie się fazy benzynowej i utworzenie warstwy alkoholowo-wodnej o grubości około $13 \mathrm{~cm}$, zawierającej około 4501 etanolu.

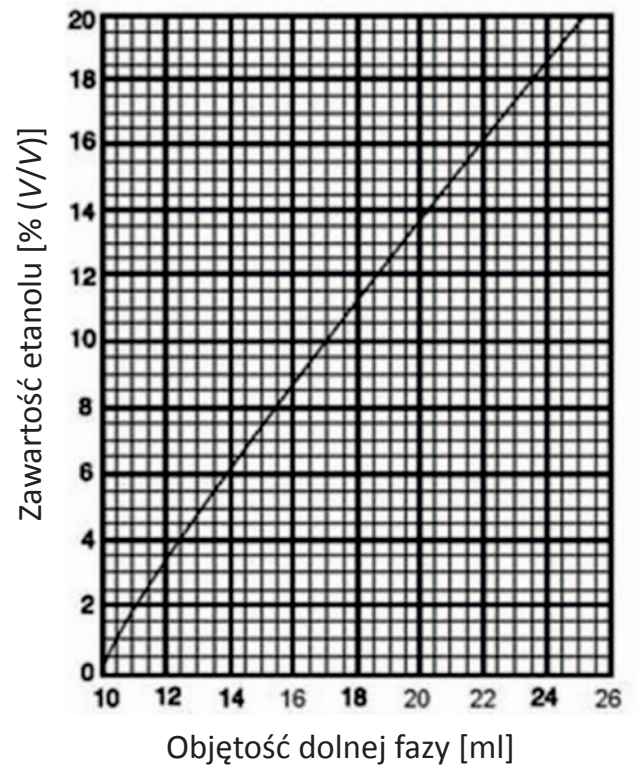

Rys. 4. Oznaczanie zawartości etanolu w benzynach etanolowych metodą ekstrakcji wodą (według [20]) 


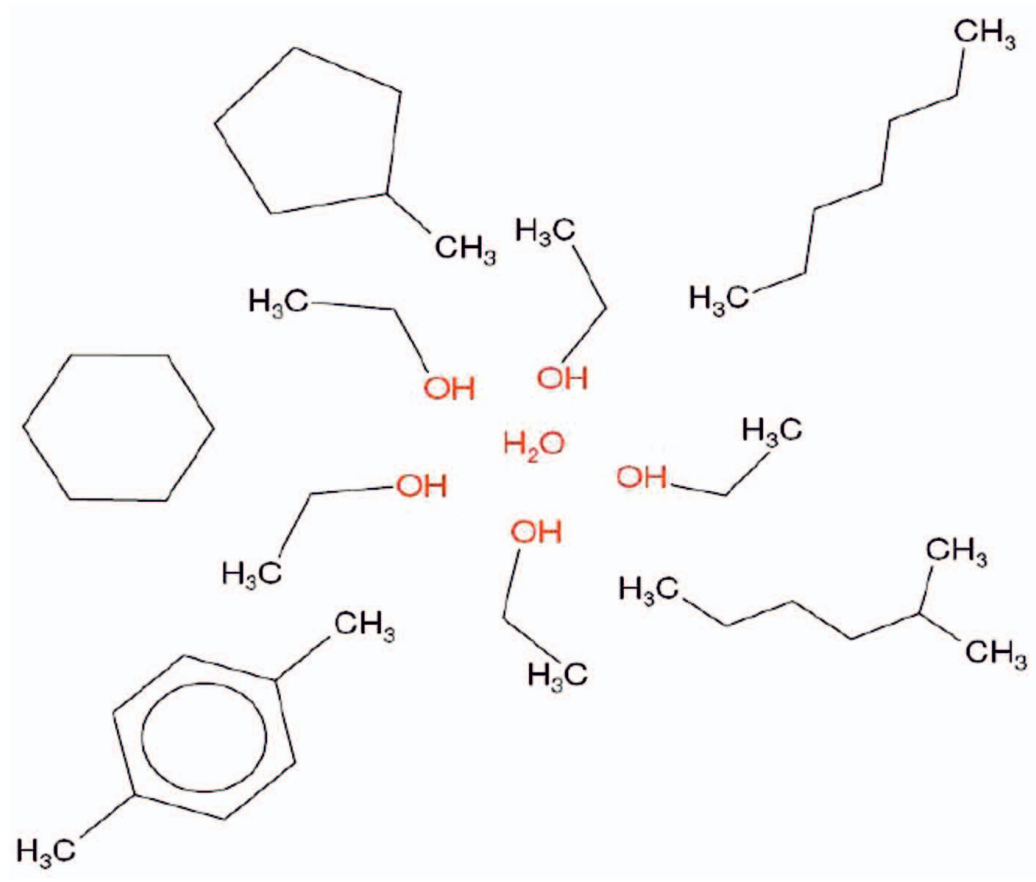

Rys. 5. Schemat wiązania koordynacyjnego cząsteczki wody w paliwie z etanolem (według [12])
Po zmieszaniu benzyny z wodą następuje praktycznie natychmiastowe rozdzielenie obu faz, z których dolna zawiera praktycznie czystą wodę, a górna - benzynę z kilkoma dziesiątymi procent wody. Etanol natomiast rozpuszcza się w wodzie nieograniczenie, jego odwodnienie jest trudne i wymaga innych procesów rozdziału, a efektem destylacji jest azeotrop, zawierający około $4 \%$ wody. W przypadku mieszaniny trójskładnikowej etanol-woda-benzyna można przypuszczać, że w skali molekularnej tworzą się struktury koordynacyjne o postaci przedstawionej na rysunku 5, w których cząsteczka wody koordynuje z pomocą wiązań wodorowych cząsteczki etanolu, których rodnik węglowodorowy wykazuje powinowactwo do węglowodorów benzyny i tym samym zapewnia trwałość (brak rozwarstwienia komponentów) takiej struktury.

Badania Bromberga i Blumberga [4] poświęcono możliwości zastosowania alkoholu etylowego o różnej zawartości wody jako komponentu benzyny.
Ciekawy sposób przybliżonego oznaczania etanolu w benzynach etanolowych, metodą ekstrakcji wodą, opisano w publikacji RFA [20]. Do cylindra pomiarowego o pojemności $100 \mathrm{ml}$, zamykanego szklanym korkiem na szlifie, wprowadza się $100 \mathrm{ml}$ mieszaniny etanol-benzyna, a następnie - pipetą $-10 \mathrm{ml}$ wody. Mieszaninę wytrząsa się przez około minutę i pozostawia do odstania na dwie minuty. Odczytuje się objętość fazy dolnej (wodno-alkoholowej) i na podstawie wykresu określa się zawartość alkoholu (rysunek 4). Dla przykładu, objętość dolnej fazy $\sim 17 \mathrm{ml}$ odpowiada benzynie zawierającej 10\% $(V / V)$ etanolu, a $\sim 25 \mathrm{ml}$ - benzynie z 20\% (V/V) etanolu.

W pracy Gramajo de Doz i wsp. [10] potwierdzono przypuszczenie, że po kontakcie z wodą ilość etanolu w fazie benzynowej maleje w miarę opróżniania zbiornika (przechodzenie etanolu do fazy gazowej), a jego zawartość w benzynie niewiele się zmienia w zależności od temperatury.

Jak wiadomo [29], we współcześnie komponowanych paliwach etanolowych wykorzystywany jest przede wszystkim bezwodny alkohol etylowy ( $<1 \%$ wody). Wiąże się to $\mathrm{z}$ koniecznością stosowania w procesie wytwarzania bioetanolu paliwowego dodatkowego, poza destylacją, procesu technologicznego, to jest odwadniania uzyskiwanego azeotropu, co generuje dodatkowe koszty. Pojawily się zatem prace badające możliwość bezpośredniego wykorzystania uwodnionego alkoholu do sporządzania mieszanek biopaliw.

Interesujące informacje dotyczące zastosowania uwodnionego etanolu jako komponentu benzyny przedstawiono w pracy Keukena i wsp. [12].

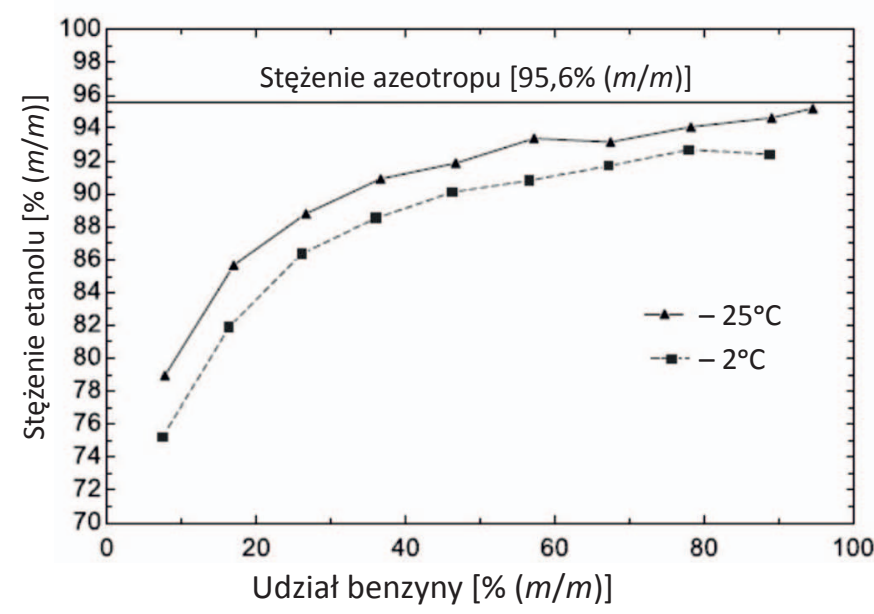

Rys. 6. Czystość etanolu (stężenie etanolu w mieszaninach etanol-woda) wymagana w celu uniknięcia rozdzielenia faz jako funkcja stężenia benzyny w dwóch różnych temperaturach (według [4])

Czysty etanol ma temperaturę krzepnięcia około $169 \mathrm{~K}$ $\left(-104,1^{\circ} \mathrm{C}\right)$, jednak $\mathrm{z}$ dodatkiem wody temperatura ta gwałtownie rośnie i aby utrzymać ją na poziomie $-40^{\circ} \mathrm{C}$ w mieszaninie musi być mniej niż $40 \%$ wody. Na rysunku 6 pokazano wyniki badań mieszanin woda-etanol-benzyna w dwóch temperaturach, to jest $-2^{\circ} \mathrm{C}$ i $-25^{\circ} \mathrm{C}$. Poszczególne punkty odpowiadają rozwarstwianiu się układu złożonego z benzyny i alkoholu o określonej zawartości wody, odpowiednio w obu temperaturach badania.

Przykładowo w temperaturze $-25^{\circ} \mathrm{C}$ w mieszance etanol-benzyna zawierającej $6 \%(\mathrm{~m} / \mathrm{m})$ benzyny maksymalna zawartość wody wynosi około $20 \%(\mathrm{~m} / \mathrm{m})$. 
Pojawiły się również odpowiednie patenty opisujące możliwość wykorzystania alkoholu etylowego z destylacji bezpośredniej do produkcji biopaliw. Na przykład patent
WO 2006/137725 [30], opisujący kompozycje paliw silnikowych zawierających od $1 \%$ do $50 \%(\mathrm{~m} / \mathrm{m})$ etanolu oraz wodę w ilości od $1 \%$ do $10 \%(\mathrm{~m} / \mathrm{m})$, w zależności od masy etanolu.

\section{Część doświadczalna}

W dotychczasowych pracach Instytutu dobrze rozpoznano wpływ zawartości etanolu w zakresie $5 \div 10 \%(V / V)$ na tolerancję wodną benzyny silnikowej. Można przypuszczać, że wyższe zawartości etanolu w benzynie silnikowej stwarzać będą podobne zagrożenia, skutkujące w konsekwencji rozwarstwieniem benzyny czy to w zbiorniku samochodu, czy w zbiorniku stacji paliw. Niniejsze opracowanie miało na celu zbadanie benzyny silnikowej o składzie chemicznym charakterystycznym dla krajowych rafinerii i zawierającej bioetanol paliwowy w ilości $15 \div 25 \%(V / V)$. Powyższy zakres udziału etanolu został zaproponowany w związku z najnowszymi światowymi informacjami o kierunkach badań i zastosowań etanolu do benzyn silnikowych. Ze względu na obecne zaintereso- wanie Komisji Europejskiej zwiększaniem udziału komponentów pochodzących z biomasy w paliwach tradycyjnych, a także informacje o prowadzonych już w UE pracach w tym zakresie istnieje potrzeba podejmowania tych badań w Polsce dla uzyskania odpowiedniej wiedzy. Dane zebrane w wyniku przedstawionych badań zostaną wykorzystane do opracowania w przyszłości sposobów postępowania w sytuacjach narażenia nowego paliwa na zawodnienie. Zaprezentowany powyżej przegląd stanu wiedzy potwierdza przekonanie o konieczności zbadania zarówno zachowania się krajowych benzyn zawierających etanol $\mathrm{w}$ ilościach przekraczających dopuszczoną obecnie ich zawartość, jak i wpływu alkoholi $\mathrm{C}_{3} \mathrm{i}_{4} \mathrm{C}_{4}$ na graniczne temperatury tworzenia układu dwufazowego.

\section{Metody badań i użyte komponenty}

Badania prowadzono $\mathrm{z}$ wykorzystaniem aktualnych wersji znormalizowanych metod badawczych.

- Do sporządzenia benzyn etanolowych E15, E20 i E25, a także E15IPA, E20IPA i E25IPA z dodatkiem 1\% $(V / V)$ izopropanolu i E15IBA, E20IBA i E25IBA z dodatkiem $1 \%(V / V)$ izobutanolu zastosowano:benzynę bazową niezawierającą związków tlenowych, spełniającą wymagania normy przedmiotowej PN-EN 228:2013-04;

- krajowy bioetanol bezwodny (oznaczona zawartość wody wynosi $0,149 \%(\mathrm{~m} / \mathrm{m}))$, spełniający wymagania rozporządzenia Ministra Gospodarki z dnia 14 maja 2015 r.;

- propan-2-ol (izopropanol) IPA, o czystości odczynnikowej;

- izobutanol IBA, o czystości odczynnikowej.
Założono wykonanie badań trzech mieszanek benzyn, zawierających różne ilości bioetanolu:

- E15 - benzyna bazowa węglowodorowa i etanol bezwodny w ilości $15 \%(V / V)$;

- E20 - benzyna bazowa węglowodorowa i etanol bezwodny w ilości $20 \%(V / V)$;

- E25 - benzyna bazowa węglowodorowa i etanol bezwodny w ilości $25 \%(V / V)$.

Badanie miało na celu ocenę wpływu wody na stabilność powyższych mieszanek. W analogiczny sposób przeprowadzono ocenę wpływu dodatku, w ilości 1\% $(V / V)$, dwóch alkoholi (izopropanolu i izobutanolu) na stabilność mieszanek badanych benzyn etanolowych.

\section{Wyniki badań}

Celem ułatwienia interpretacji uzyskanych wyników pomiarów mieszalności badanych kompozycji benzynowych poniżej zaprezentowano wybrane rezultaty w formie wykresów.

Na rysunku 7 przedstawiono wyniki pomiarów benzyny E15 dotyczące temperatury mętnienia oraz temperatur wypadania i resorpcji fazy wodnej oraz ich średniej, przyjmowanej jako temperatura rozwarstwiania kompozycji.

Należy zauważyć, że podczas wcześniejszych badań Pałuchowskiej [16] zaobserwowano wyraźną krzywą histerezy zależności temperatury przemiany fazowej mieszaniny woda-benzyna etanolowa - różnice pomiędzy temperaturami wypadania i resorpcji fazy wodnej dla kompozycji zawie- rających $8 \%$ i $10 \%(V / V)$ bioetanolu osiągały odpowiednio nawet do $22^{\circ} \mathrm{C}(8 \%(V / V))$ czy $20^{\circ} \mathrm{C}(10 \%(V / V))$.

Przy zawartości $15 \%(V / V)$ etanolu analogiczne różnice temperatur drastycznie maleją i nie przekraczają praktycznie $1^{\circ} \mathrm{C}$

Rysunek 8 przedstawia zestawienie analogicznych danych umożliwiających porównanie badanych parametrów przy zwiększającym się udziale etanolu w kompozycjach paliwowych.

Zestawienie wyników badań kompozycji benzyn o rosnącej zawartości etanolu, oprócz potwierdzenia malejących różnic temperatur wypadania i resorpcji fazy wodnej, 


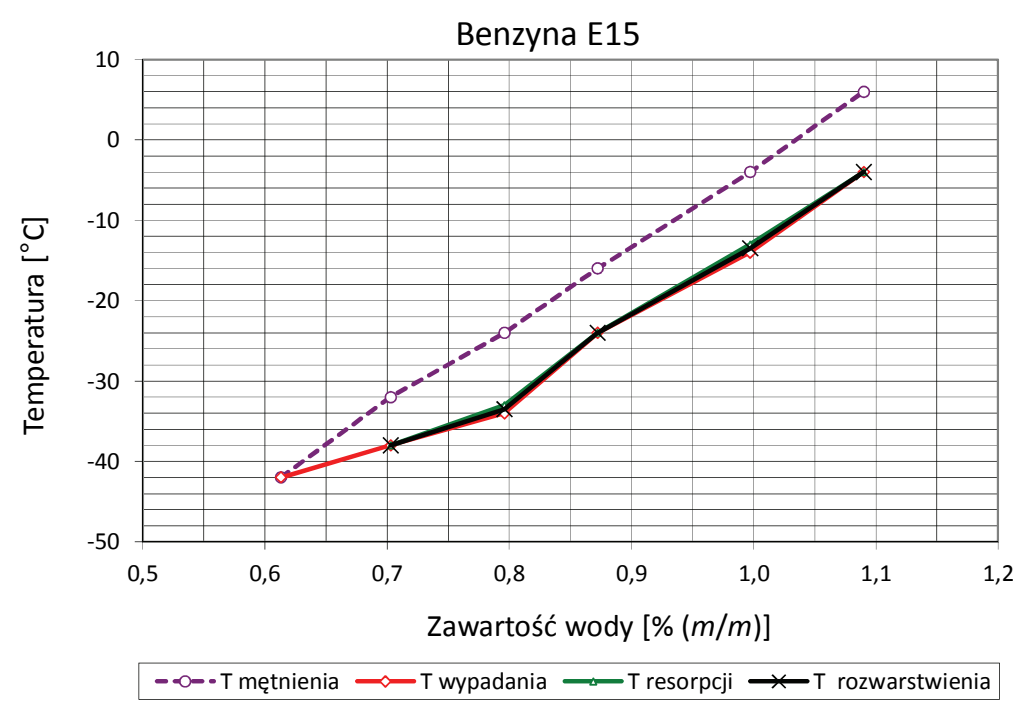

Rys. 7. Stabilność temperaturowa mieszanek benzyny E15 z wodą

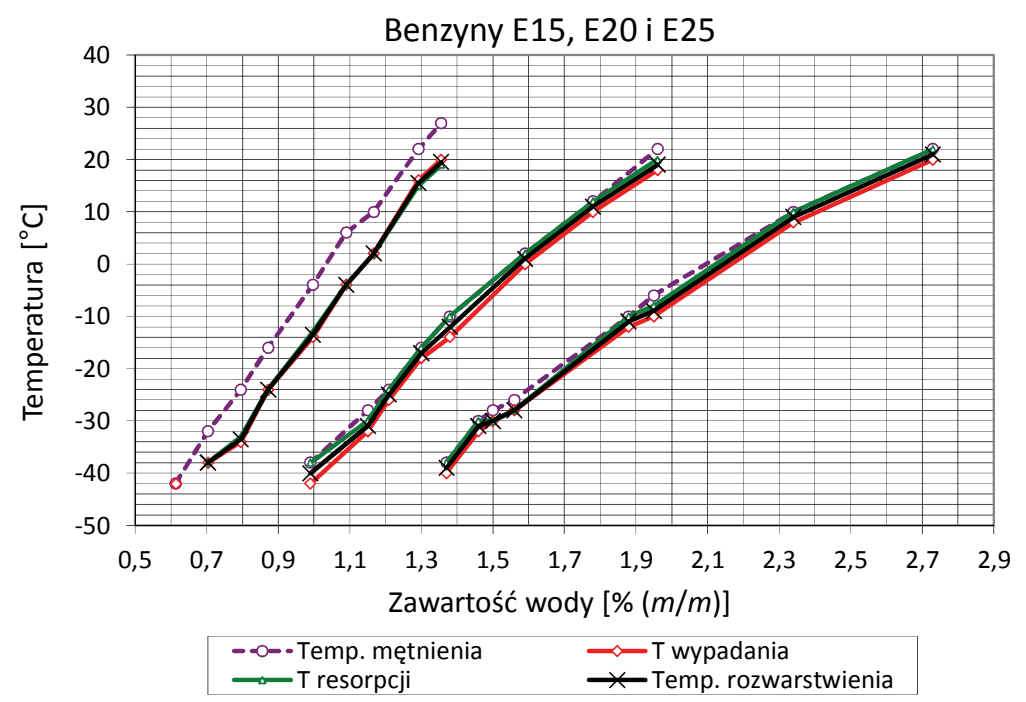

Rys. 8. Porównanie stabilności temperaturowej mieszanek kompozycji benzyn E15 do E25 z wodą rozwarstwiania się pod wpływem wody. Można zatem przypuszczać, że obserwowany efekt wiąże się raczej ze zwiększeniem całkowitego stężenia alkoholi w mieszaninie niż $\mathrm{z}$ charakterem chemicznym wprowadzonego alkoholu. Podobne zjawisko zaobserwowano w przypadku kompozycji paliwa E25, z tym, że można tu wyraźniej zauważyć zarówno wspomniane już zwiększenie czułości zmian temperatury na tolerancję na obecność wody (zmniejszenie różnicy temperatur mętnienia i rozdziału faz), jak i zmniejszenie wpływu dodatku izopropanolu lub izobutanolu na temperaturę rozdziału faz (sumaryczna zawartość alkoholi w paliwie E25 zmienia się z 25\% na 26\%).

Na rysunku 10 przedstawiono zmiany temperatur rozwarstwiania wszystkich badanych próbek benzyn etanolowych, również zawierających dodatek alkoholi izopropylowego i izobutylowego w ilości 1\% ( V/V), uzupełniając je o wynik badania paliwa E6 według [14].

Przedstawione dane potwierdzają wcześniejsze obserwacje, że zmiany temperatury powstawania fazy wodnej benzyn $z$ bioetanolem pod wpływem dodatku współrozpuszczalnika alkoholowego przy niskich temperaturach w niewielkim stopniu zależą od jego rodzaju, a raczej od sumarycznej zawartości komponentów hydrofilowych (alkoholi). Z rysunku można także odczytać, jaką ilość wody mogą pochłonąć poszczególne benzyny etanolowe przy określonej temperaturze rozwarstwienia. Przykładowo w temperaturze $-20^{\circ} \mathrm{C}$ rozwarstwienie benzyny E6 występuje przy zawartości wody $0,25 \%(\mathrm{~m} / \mathrm{m})$, benzyny pozwala zauważyć dodatkowo zwiększenie czułości kompoE15 przy zawartości wody około $0,92 \%(\mathrm{~m} / \mathrm{m})$, benzyny E20 zycji na temperaturę przemiany fazowej, zmniejsza się bowiem różnica pomiędzy zaobserwowanymi temperaturami mętnienia i odpowiadającymi im temperaturami rozwarstwiania mieszanin. Można to interpretować jako zwiększoną zdolność do koalescencji zawieszonych mikrokropli wody, powodowaną ich większą ilością w jednostce objętości. Zawartość wody utrzymującej się w badanych benzynach rośnie bowiem wraz ze stężeniem w nich etanolu.

Na kolejnym rysunku (rysunek 9) zaprezentowano wpływ dodatku izopropanolu oraz izobutanolu na właściwości benzyny E15.

Uzyskane wyniki oznaczań wskazują na niemal jednakowy wpływ obu badanych alkoholi (izopropanol i izobutanol) na skłonność benzyny E15 do

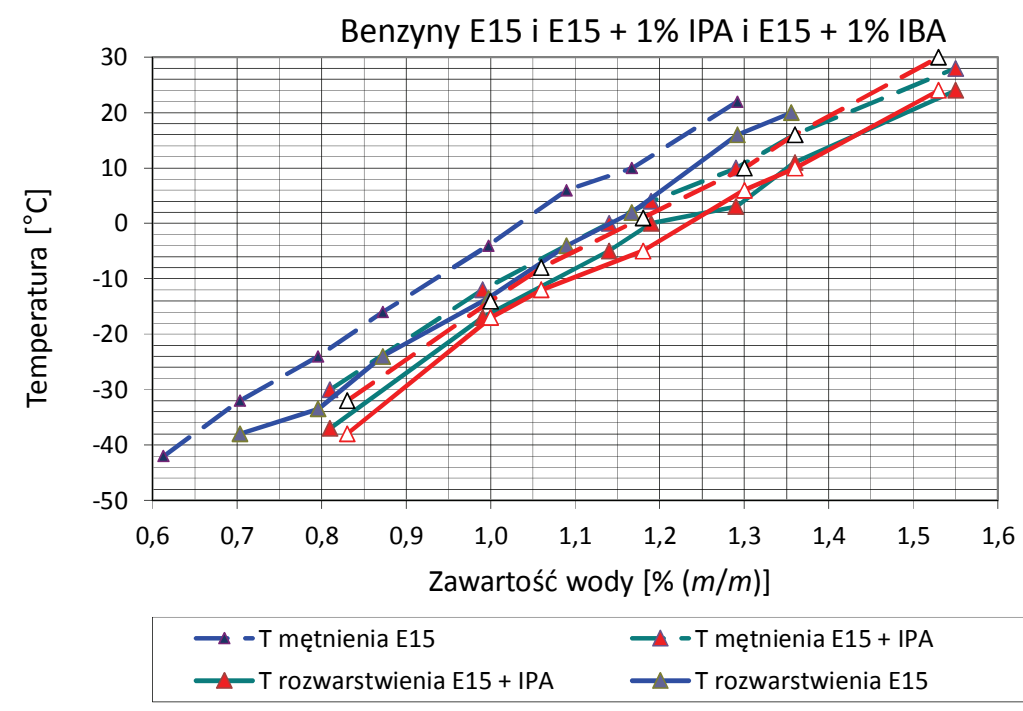

Rys. 9. Wpływ dodatku badanych alkoholi na tolerancję wody paliwa E15 


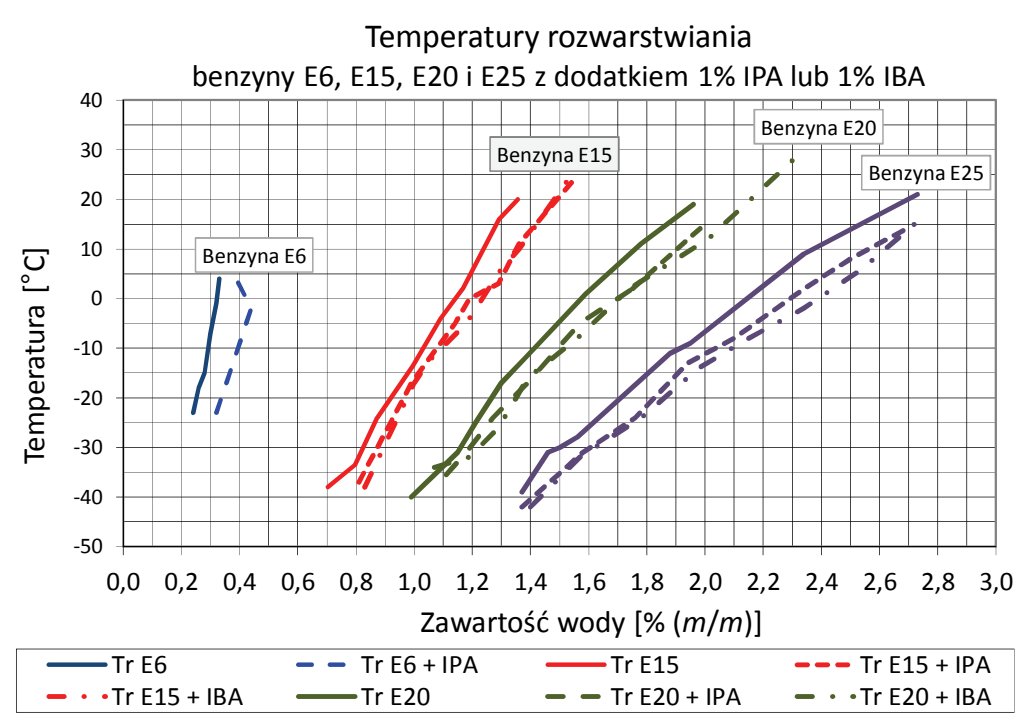

Rys. 10. Wpływ dodatku badanych alkoholi na tolerancję wodną kompozycji benzyny z etanolem przy zawartości wody około 1,26\% $(\mathrm{m} / \mathrm{m})$ i benzyny E25 przy zawartości wody około $1,7 \%(\mathrm{~m} / \mathrm{m})$. Dla benzyn etanolowych zawierających współrozpuszczalnik w postaci alkoholu izopropylowego lub izobutylowego możliwa do pochłonięcia ilość wody dla poszczególnych benzyn wzrasta o około $0,1 \%(\mathrm{~m} / \mathrm{m})$.

Należy zauważyć, że $0,1 \%(\mathrm{~m} / \mathrm{m})$, o którą można zwiększyć zawartość wody z zastosowaniem współrozpuszczalników, w przypadku benzyny E6 stanowi 40\% wyjściowej zawartości wody, przy której następuje rozwarstwienie, a w przypadku benzyny E25 stanowi niecałe 6\% wyjściowej zawartości wody. Zatem stosowanie współrozpuszczalników dla obniżenia temperatury rozwarstwienia w benzynach o wysokiej zawartości etanolu staje się nieuzasadnione.

\section{Podsumowanie}

Przeprowadzone badania pozwoliły na pozyskanie wiedzy na temat tzw. tolerancji wodnej benzyn etanolowych o zróżnicowanej zawartości wody, zawierających etanol w zakresie od $15 \%$ do $25 \%(V / V)$, a także współrozpuszczalniki w postaci alkoholi izopropylowego i izobutylowego na poziomie $1 \%(V / V)$. Miarą tolerancji wodnej jest temperatura rozwarstwienia mieszaniny benzyna-etanol-woda $\mathrm{w}$ trakcie ochładzania. Badaniom poddano benzyny E15, E20 i E25 skomponowane $\mathrm{z}$ udziałem bazowej benzyny węglowodorowej i krajowego bioetanolu. Wybrane wyniki badań wraz $\mathrm{z}$ ich interpretacją przedstawiono na rysunkach zbiorczych, a także porównano z wynikami wcześniejszych prac o podobnej tematyce dla benzyn etanolowych o niższej zawartości etanolu. Zdobyta wiedza pozwoli na oszacowanie zagrożeń związanych z rozwarstwianiem się benzyn etanolowych w kontakcie z wodą, która może przedostawać się do nich między innymi podczas transportu i w trakcie magazynowania. Dane zawarte w pracy pozwalają na oszacowanie ilości wody, którą może pochłonąć benzyna etanolowa w określonej temperaturze, bez utraty jednorodności, a także temperatury rozwarstwiania benzyn etanolowych z określoną zawartością etanolu i wody.

\section{Wnioski}

1. Zwiększanie zawartości etanolu w przedziale $15 \div 25 \%(V / V)$ w benzynach etanolowych zawierających wodę powoduje systematyczne obniżanie temperatury rozwarstwienia mieszaniny trójskładnikowej.

2. Stosowanie współrozpuszczalników celem obniżenia temperatury rozwarstwienia benzyn etanolowych zawierających etanol w ilości $15 \div 25 \%(V / V)$ jest mało efektywne.
3. Różnica pomiędzy temperaturą mętnienia obserwowaną w trakcie ochładzania benzyn etanolowych zawierających wodę a temperaturą rozwarstwiania w miarę wzrastającego stężenia etanolu zmniejsza się i dla benzyn E20 i E25 temperatury te praktycznie się pokrywają ), co świadczy o rosnącej nietrwałości zawiesiny fazy wodno alkoholowej w paliwie.

Prosimy cytować jako Nafta-Gaz 2016, nr 5, s. 374-355, DOI: 10.18668/NG.2016.05.

Artykuł przysłano do Redakcji 10.11.2015 r. Zatwierdzono do druku 11.02.2016 r.

Artykuł powstał na podstawie pracy statutowej pt. Badanie wptywu zawartości $15-25 \%$ (V/V) etanolu na tolerancję wodna benzyny silnikowej - praca INiG - PIB na zlecenie MNiSW; nr zlecenia: 0001/TA/15/01, archiwalny: DK-4100-01/15. 


\section{Literatura}

[1] Bioethanol use in Europe and globally; http://www.biofuelstp. eu/bioethanol.html (dostęp: wrzesień 2015).

[2] Bradley C., Runnion K.: Understanding Ethanol Fuel Production and Use. Tech. pap. No 3. ISBN: 0-86619-203-4 [C] 1984; http://www.appropedia.org/Understanding_Ethanol_ Fuel_Production_and_Use (dostęp: wrzesień 2015).

[3] Bridgeman O. C., Querfeld D.: Critical Solution Temperatures of Mixtures of Gasoline, Ethyl Alcohol, and Water. Bureau of Standards Journal of Research 1933, vol. 10, s. 693-704; http://nvlpubs.nist.gov/nistpubs/jres/10/jresv10n5p693_A2b. pdf (dostęp: wrzesień 2015).

[4] Bromberg L., Blumberg P.: Estimates of DI Hydrous Ethanol Utilization for Knock Avoidance and Comparison to a Measured and Simulated DI E85 Baseline. 2009; http://dspace. mit.edu/bitstream/handle/1721.1/94308/09ja033 full.pdf?sequence $=1$ (dostęp: wrzesień 2015).

[5] Central Illinois Manufacturing Co.: Switching to ethanol? Guidelines for Conversion of Retail Service Station Tanks from Gasoline to Ethanol - Blended Gasoline, http://www. maine.gov/dep/air/mobile/documents/converting.pdf (dostęp: wrzesień 2015).

[6] Danek B.: Biopaliwo o zawartości 20 $\div 25 \%(V / V)$ etanolu, wybrane właściwości fizykochemiczne. Nafta-Gaz 2015, $\mathrm{nr} 4$, s. 223-229.

[7] Dutchak V., Astakhova O., Kvitkovsky L.: Reciprocal solubility of gasoline fractions and ethanol. Chemistry and Chemical Technology 2011, vol. 5, no. 2, s. 215-220.

[8] Egebaeck K. E., Henke M., Rehnlund B., Wallin M., Westerholm R.: Blending of Ethanol in Gasoline for Spark Ignition Engines. Problem Inventory and Evaporative Measurements. AVL MTC Motortestcenter AB, Report 5407, 2005; http:// growthenergy.org/images/reports/avl_ethanol_sparkignition. pdf (dostęp: wrzesień 2015).

[9] Ethanol Fuel History; http://www.fuel-testers.com/ethanol_fuel_history.html (dostęp: wrzesień 2015).

[10] Gramajo de Doz M. B., Bonatti C. M., Sólimo H. N.: Water Tolerance and Ethanol Concentration in Ethanol-Gasoline Fuels at Three Temperatures. Energy Fuels 2004, vol. 18, no. 2, s. 334-337.

[11] Jain S.: Ethanol-Water Phase Separation. White Paper; http:// www.veeder.com/gold/download.cfm?doc_id=6935 (dostęp: wrzesień 2015).

[12] Keuken H., MacDonald T., de Jager E., Sijben J.: Hydrous Ethanol for Gasoline Blending. New Science Promises Cost and Energy Savings. $17^{\text {th }}$ International Symposium on Alcohol Fuels. Tiayuan, China, 13-16.10.2008; http://www.heblends. com/media/publications/ISAF_XVII_Hydrous_Ethanol_Paper.pdf (dostęp: wrzesień 2015).

[13] Korotney D.: Water Phase Separation in Oxygenated Gasoline; https:/www.epa.gov/sites/production/files/2015-09/ documents/waterphs.pdf (dostęp: wrzesień 2015).

[14] Pałuchowska M.: Badanie efektywności wspótrozpuszczalników w zawodnionej benzynie silnikowej o zawartości

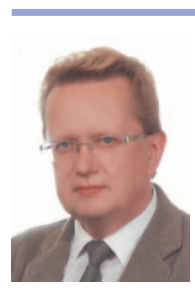

Mgr Marek KWINTA

Starszy specjalista badawczo-techniczny; zastępca Kierownika Zakładu Analiz Naftowych. Instytut Nafty i Gazu - Państwowy Instytut Badawczy ul. Lubicz $25 \mathrm{~A}$

31-503 Kraków

E-mail: kwinta@inig.pl powyżej 5\% (V/V) bioetanolu. Praca niepublikowana, $\mathrm{nr}$ arch. DK-4100-82/10, wrzesień 2010.

[15] Pałuchowska M.: Wpływ rafineryjnej formuly komponentowej paliw etanolowych na ich parametry fizykochemiczne i użytkowe. Prace Naukowe INiG - PIB 2012, nr 181.

[16] Pałuchowska M.: Wpływ wspótrozpuszczalnika na zjawisko rozdziału faz w benzynie silnikowej zawierajacej do $10 \%(\mathrm{~V} / \mathrm{V})$ bioetanolu. Nafta-Gaz 2011, nr 6, s. 428-432.

[17] Pałuchowska M., Danek B.: Specyfikacje jakościowe bioetanolu i biopaliw do silników o zapłonie iskrowym. Nafta-Gaz 2009, nr 2, s. 174-182.

[18] Phase separation; http://ethanolpro.tripod.com/id162.html (dostęp: wrzesień 2015).

[19] Prakash Ch.: Use of Higher than 10 volume percent Ethanol/ Gasoline Blends in Gasoline Powered Vehicles. 1998; http:// www.desenvolvimento.gov.br/arquivos/dwnl_1399915126. pdf (dostęp: wrzesień 2015).

[20] RFA (Renewable Fuel Association): Fuel Ethanol. Industry Guidelines, Specifications and Procedures. December 2010; http://ethanolrfa.3cdn.net/0d3394a26bc8e81135_bum6brcyy. pdf (dostęp: wrzesień 2015).

[21] Stępień Z.: Zagrożenia eksploatacyjne stwarzane przez paliwa etanolowe dla silników o zapłonie iskrowym. Prace Naukowe Instytutu Nafty i Gazu Państwowego Instytutu Badawczego No 204.

[22] Summary of the main ethanol blends used around the World; https://en.wikipedia.org/wiki/Common_ethanol_fuel_mixtures (dostęp: wrzesień 2015).

[23] Waytulonis R., Kittelson D., Zarling D.: E20 Effects in Small Non-Road SI Engines. A Literature and Information Search. University of Minnesota 2008; http://archive.leg.state.mn.us/ docs/2008/mandated/080342.pdf (dostęp: wrzesień 2015).

[24] Weaver J. W., Skaggs S. A., Spidle D. L., Stone G. C.: Composition and Behavior of Fuel Ethanol. EPA/600/R-09/037, April 2009, s. 35, ISBN: 0-86619-203-4 [C] 1984; https:// cfpub.epa.gov/si/si_public_file_download.cfm?p_download_id=492615 (dostęp: wrzesień 2015).

\section{Akty prawne i normatywne}

[25] Dyrektywa Parlamentu Europejskiego i Rady 2009/28/WE z dnia 23 kwietnia 2009 r. w sprawie promowania stosowania energii ze źródeł odnawialnych zmieniająca i w następstwie uchylająca dyrektywy 2001/77/WE oraz 2003/30/WE.

[26] Rozporządzenie Ministra Gospodarki z dnia 14 maja 2015 r. zmieniające rozporządzenie w sprawie wymagań jakościowych dla biokomponentów, metod badań jakości biokomponentów oraz sposobu pobierania próbek biokomponentów (Dz. U. z 2015 r., poz. 780).

\section{Patenty}

[27] Patent WO 2006/137725 A1 Motor Fuel Based on Gasoline and Ethanol.

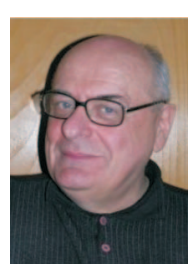

Prof. nzw. dr Michał KRASODOMSKI

Specjalista w zakresie chemii analitycznej ropy naftowej i produktów naftowych.

E-mail:krasodomski@inig.pl 